\title{
The experience of an Academic League: the positive impact on knowledge about trauma and emergency
}

\section{A experiência de uma Liga Acadêmica: impacto positivo no conhecimento sobre trauma e emergência}

Luciana Thurler Tedeschi ${ }^{1}$; Luiz Paulo Junqueira Rigolon ${ }^{1}$; Flávio de Oliveira Mendes ${ }^{1}$; Marianna Martini Fischmann ${ }^{1}$; Isabella de Almeida Klein ${ }^{1}$; Valéria Troncoso Baltar ${ }^{2}$.

\section{A B S T R A C T}

\begin{abstract}
Objective: to evaluate the knowledge growth of the members of the Trauma, Resuscitation and Emergency League in comparison with a nonparticipating group, with similar characteristics, at the Fluminense Federal University. Methods: we evaluated 50 league members and 50 non-members (control group) through questionnaires applied at the beginning and end of a school year. We used a generalized linear model, with interaction effect between groups and tests (multiple comparisons with Bonferroni correction). We included the following control variables: gender, period, age, and attendance to some other course on a similar topic. Results: there was an increase of 22 percentage points $(p<0.001)$ for the group with more than $75 \%$ presence in the League compared with the eight points in the control group $(p<0.05)$. There was no statistically significant growth for the group with less than $75 \%$ presence. Conclusion: the growth of knowledge was significantly higher in the group that assiduously participated in the League, which reinforces its importance in complementing the traditional content of medical courses.
\end{abstract}

Keywords: Teaching. Education, Medical. Students, Medical. Emergencies. Traumatology.

\section{INTRODUCTION}

$T^{\mathrm{t}}$ he number of medical schools in Brazil has steadily increased, with an average of approximately 19,000 physicians graduating each year ${ }^{1}$. Currently, the country has 279 public and private universities, behind only 381 schools in India, the country with the first position in the world ranking and with population six times greater than the Brazilian'. The maintenance of teaching quality is fundamental and, even more relevant, when it comes to learning about trauma and emergency, due to the occupation of shifts in emergency rooms by newly graduated doctors ${ }^{2}$.

According to data from the Mortality Information System (SIM), there were 152,135 deaths from external causes in Brazil in 2015². This number represents the third leading cause of death in the country in the same year, behind only mortality due to diseases of the circulatory system and neoplasias ${ }^{3}$. The investments in trauma in Brazil are approximately $\mathrm{R} \$ .300,00$ per capita per year, with costs that reach $R \$ .100,000.00$ in serious victims ${ }^{4}$. Additionally, the social impact of accidents and violence can be verified by the $30 \%$ increase in the Potential Years of Life Lost (PYLL) observed in the last decades. This tendency is not accompanied by the index of death due to natural causes, which, on the contrary, is in decline. Clinical emergencies also imply direct and indirect costs with consultations, procedures, hospitalizations and loss of productivity. Urgency expenditures are about three times higher than the ones of elective hospitalizations, intensive care units and professional services ${ }^{5}$.

Despite the relevance of the theme, in almost all Brazilian universities, there are no programs for teaching trauma and medical emergencies in the curricular matrix of the medical courses ${ }^{2}$. In order to change this reality, in a still incipient way, in 2013, Law 12,871 was enacted, which, in article 40 , item I, establishes a workload of at least $30 \%$ of the undergraduate medical internship in Primary Care and Emergency facilities of the Brazilian Unified Health System (SUS) ${ }^{6}$. As a complementary methodology, a relevant portion of this content has

1 - Fluminense Federal University, Faculty of Medicine, Niterói, RJ, Brazil. 2 - Fluminense Federal University, Department of Epidemiology and Biostatistics, Niterói, RJ, Brazil. 
been contemplated by extracurricular activities such as Academic Leagues.

The Leagues are formed by students of courses in the area of health, coordinated by professionals associated with the institution or the teaching hospital ${ }^{7}$ and governed by their own statute. They basically offer structures that cover the tripod teaching, research and extension, through seminars, classes, discussions, presentations of clinical cases, practical activities, contact with patients, internships, publications of articles, among others. The leagues are maintained by a self-sustaining financial system in which courses and workshops are provided and funds are raised from corporate sponsorship and university scholarships. They are entities that have been gradually gaining space in the university environment because of their potential contribution to teaching ${ }^{8}$. However, the leagues' impact on cognitive development, on the pedagogical function within institutions, and on students' academic performance is poorly studied ${ }^{9,10}$.

The League of Trauma, Resuscitation and Emergency (LiTRE) is a project of the Fluminense Federal University (UFF), in association with the Department of General and Specialized Surgery of the Faculty of Medicine, composed of medical graduates and other courses in the health area, and professionals of the institution itself and the health network of Niterói. LiTRE came up with the mission of stimulating the study of clinical emergencies and trauma, aiming at the better training of students and the quality of attending to society. It is formed by 50 students, admitted through a selective process, structured from theoretical lectures in a symposium offered with invited speakers from renowned institutions. Its board of directors consists mainly of those members who stood out during the year. It promotes theoretical-practical classes, given every two weeks in the prehospital, emergency and intra-hospital areas; provides internships that aim to bring participants closer to medical activity and to patients; encourages scientific research and work; and holds events focused on the population.

The objective of the present study was to evaluate the effect of the activities offered by the League of Trauma, Resuscitation and Emergency on the knowledge acquired by its participants, when compared with a control group. Specifically, we intended to quantitatively verify the effectiveness of the content developed by LiTRE over one year.

\section{METHODS}

We conducted a prospective study with two groups balanced by academic period. The exposure variable was the participation in the LiTRE activities, and we carried out the evaluation in two moments: at the beginning of the activities of the League and at their conclusion, for the exposed sample, corresponding to the months of May 2016 and March 2017, respectively. For the group not exposed to the league's activities in that period, we performed two tests in the same periods of the league members group.

We invited participants to respond to a questionnaire created by the board members, composed of 20 multiple-choice questions developed according to the programmatic content demonstrated during the course, so that each questionnaire differs according to the category of the participant (pre-hospital, emergency, in-hospital). The different topics addressed during the weekly theoretical-practical classes in each segment justify the different questionnaires, to relativize the degree of achievement according to the category of the course and period for non-members. Among the contents evaluated in the questionnaires are fundamental issues to medical training, such as basic and advanced life support, burns, drowning, disasters and accidents with multiple victims, trauma, ischemic and hemorrhagic stroke, shock, sepsis, acute coronary syndrome, disorders of hydroelectrolytic and acid-base balance, access to airways, electrical and cardioversion therapies, post-resuscitation care and sedation. The board members responsible for each respective area applied the questionnaires after specific training to standardize data collection. Students were not notified that the tests were the same in both applications and the questions were not commented or corrected to avoid anticipation of the second test over the first. Variables related to age, gender, attendance in classes, period (semester) of Medicine course, and previous participation in another trauma/emergency course/activity were also collected.

Initially, the sample comprised 112 medical students at the Fluminense Federal University, with a response frequency of $89.3 \%$, so that at the end of the study, 100 questionnaires were answered by pre-hospital students, between the 3rd and the 5th period, emergency 
students, between the 5th and 7th periods and the intrahospital hospital, between the 7th and 10th periods. We excluded from the study all students participating in the league who dropped out and/or refused to answer the questionnaire. We formed the control group with students with the same criteria of number of participants and academic period, chosen by random draw.

Due to the large frequency variation in classes for students who participated in the course, we reclassified the league members in groups with $<50 \%$, between $50-75 \%$ and with $>75 \%$ attendance in classes We carried out a descriptive analysis of the data, with the basic characteristics of the sample. The scores were converted in percentage points from 0 to 100 according to the proportion of correctness in both tests. We used a generalized linear model (GLM) to evaluate the mean scores in the first (P1) and second (P2) tests in each of the four groups (control, attendance $<50 \%$, between 50 and $75 \%$ and $>75 \%$ ) with effect of groups and tests, and an interaction between groups and tests, controlling for gender, period, age and some other course on a similar theme. The multiple comparisons of the average scores between the interaction groups were corrected by the Bonferroni method. The analyzes were performed in the Statistical Package for Social Sciences (SPSS version 21) for Windows. A significance level of $5 \%$ was considered in all analyzes.

Participation was entirely voluntary and responses were anonymous. UFF's Ethics in Research Committee approved this study and all participants signed informed consent forms (CAAE: 55267216.1.0000.5243).

\section{RESULTS}

The study sample consisted of 56 students belonging to the control group and 44 LiTRE members. The mean age was 22.87 years (Standard Deviation 2.93), with $80 \%$ concentrated between 20 and 24 years. Of the sample, $57 \%$ were women. The majority of the participants did not perform any previous trauma or emergency course $(n=71)$. At the beginning of the study, students were between the 3rd and 10th periods of medical graduation, mainly in the second and third years (Table 1).

Table 1. Characteristics of control and LiTRE groups and frequency of attendance to the League' activities.

\begin{tabular}{|c|c|c|c|c|c|c|}
\hline & & $\begin{array}{c}\text { Control } \\
(n=56 ; 56 \%)\end{array}$ & $\begin{array}{c}\text { LiTRE } \\
=50 \% \\
(n=19 ; 19 \%)\end{array}$ & $\begin{array}{c}\text { LiTRE } \\
50 \%-75 \% \\
(n=8 ; 8 \%)\end{array}$ & $\begin{array}{c}\text { LiTRE } \\
=75 \% \\
(n=17 ; 17 \%)\end{array}$ & $\begin{array}{c}\text { Total } \\
(n=100)\end{array}$ \\
\hline \multirow{2}{*}{$\begin{array}{l}\text { Attended any other course } \\
\text { in the same area? }\end{array}$} & No & $39(69.6 \%)$ & $14(73.7 \%)$ & $4(50.0 \%)$ & $14(82.4 \%)$ & 71 \\
\hline & Yes & $17(30.4 \%)$ & $5(26.3 \%)$ & $4(50.0 \%)$ & $3(17.6 \%)$ & 29 \\
\hline \multirow{2}{*}{ Gender } & Female & $32(57.1 \%)$ & $12(63.2 \%)$ & $5(62.5 \%)$ & $8(47.1 \%)$ & 57 \\
\hline & Male & $24(42.9 \%)$ & $7(36.8 \%)$ & $3(37.5 \%)$ & $9(52.9 \%)$ & 43 \\
\hline \multirow{5}{*}{ UFF Medical School Year } & 2nd year & $17(30.4 \%)$ & $12(63.2 \%)$ & $2(25 \%)$ & $2(11.8 \%)$ & 33 \\
\hline & 3rd year & $24(42.9 \%)$ & $5(26.3 \%)$ & $0(0 \%)$ & $13(76.5 \%)$ & 42 \\
\hline & 4th year & $11(19.6 \%)$ & $1(5.3 \%)$ & $5(62.5 \%)$ & $2(11.8 \%)$ & 19 \\
\hline & 5th year & $4(7.1 \%)$ & $1(5.3 \%)$ & $1(12.5 \%)$ & $0(0 \%)$ & 6 \\
\hline & Pre/hospital & $18(32.1 \%)$ & $14(73.7 \%)$ & $2(25 \%)$ & $2(11.8 \%)$ & 36 \\
\hline \multirow[t]{4}{*}{ Segment } & Emergency & $23(41.1 \%)$ & $4(21.1 \%)$ & $0(0 \%)$ & $14(82.4 \%)$ & 41 \\
\hline & In-Hospital & $15(26.8 \%)$ & $1(5.3 \%)$ & $6(75 \%)$ & $1(5.9 \%)$ & 23 \\
\hline & $<20$ & $1(1.8 \%)$ & $2(10.5 \%)$ & $0(0 \%)$ & $0(0 \%)$ & 3 \\
\hline & $20-24$ & $47(83.9 \%)$ & $13(68.4 \%)$ & $6(75 \%)$ & $14(82.4 \%)$ & 80 \\
\hline \multirow{2}{*}{ Age group } & $25-29$ & $6(10.7 \%)$ & $3(15.8 \%)$ & $1(12.5 \%)$ & $3(17.6 \%)$ & 13 \\
\hline & $=30$ & $2(3.6 \%)$ & $1(5.3 \%)$ & $1(12.5 \%)$ & $0(0 \%)$ & 4 \\
\hline
\end{tabular}

LiTRE: League of Trauma, Resuscitation and Emergency 
Considering the league and control groups, we observed that the mean score in both tests is higher for the league group. In addition, we observed a proportional increase in both groups ( $p$-value of the non-significant interaction, $p=0.081$ ). Figure 1 shows the respective groups' means in the two moments and the 95\% confidence intervals.

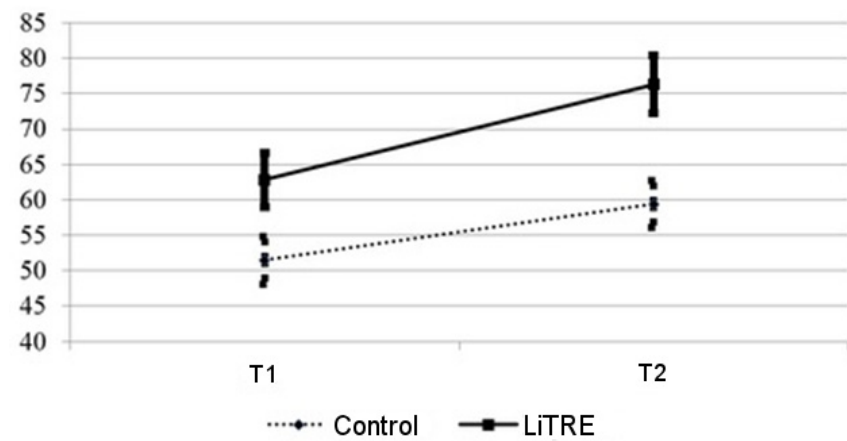

Figure 1. Means and respective $95 \%$ confidence intervals for the scores of the control and LiTRE groups between tests 1 and 2.

When reclassifying the league members according to attendance, the average score in the first test for the control group was $51.4 \%$ (SD 3.8\%); for league members with less than $50 \%$ attendance, it was $64.9 \%$ (SD 5.2\%); for attendance between 50 and $75 \%$, of $65.8 \%$ (SD 7.5\%); and with more than 75\% attendance, the mean percentage score was $58.9 \%$ (SD 6.1\%) (Table 2). After the classes and activities, or during the course of a school year for non-members, the average scores for the respective groups were $59.4 \%$ (SD 3.8\%) for the control group, $74.8 \%$ (SD 6.0\%) for the attendance less than $50 \%, 68.4 \%$ (SD 5.4\%) for the subgroup with 50 and $75 \%$ attendance, and of $81.6 \%$ (SD $7.0 \%$ ) for more than $75 \%$ attendance (Table 2 ).
Table 2. Averages and standard deviations for the percentage scores in the first and final tests for the control groups and the three subgroups of league members.

\begin{tabular}{lcc}
\hline & Test 1 & Test 2 \\
\hline Control & $51.4 \pm 1.93$ & $59.4 \pm 1.95$ \\
LiTRE $=50 \%$ & $64.9 \pm 2.66$ & $74.8 \pm 3.04$ \\
LiTRE $50-75 \%$ & $65.8 \pm 3.83$ & $68.4 \pm 2.76$ \\
LiTRE $=75 \%$ & $58.9 \pm 3.13$ & $81.6 \pm 3.55$ \\
\hline
\end{tabular}

* GLM model controlling for gender, age, school year, and attendance in another course. Effects of groups ( $f 0.001)$, tests $(p<0.001)$ and interaction of groups and tests $(p<0.001)$.

By controlling for gender, school year, age and other courses in the area, the GLM model showed an interaction effect between the groups and the two tests (Table 2). We then carried out multiple comparisons between groups and Bonferroni-corrected tests (Table 3). For example, the increase of eight mean percentage points (Table 2) from the first to the second test for the control group was statistically significant, $\mathrm{p}=0.003$ (Table 3 ). The groups of league members with less than $50 \%$ and with 50 to $75 \%$ attendance obtained, respectively, $9.9 \%$ and $2.6 \%$ increase in the score, without statistical significance ( $p=0.121$ and $p=0.999$, respectively). However, the average 22.7 percentage points increase of the league members with more than $75 \%$ participation had $p<0.001$ (Figure 2). The difference of 7.5 percentage points in the first test between the control group and LiTRE with more than $75 \%$ attendance was not significant $(p=0.668)$, both being equal at the beginning of the research.

Table 3. Results of p-values of multiple comparisons of interaction between groups and tests, with Bonferroni correction.

\begin{tabular}{|c|c|c|c|c|c|c|c|c|c|}
\hline \multirow{2}{*}{\multicolumn{2}{|c|}{$\begin{array}{l}\text { p values corrected by } \\
\text { Bonferroni }\end{array}$}} & \multicolumn{2}{|c|}{ Control } & \multicolumn{2}{|c|}{ LiTRE =50\% } & \multicolumn{2}{|c|}{ LiTRE 50-75\% } & \multicolumn{2}{|c|}{ LiTRE $=75 \%$} \\
\hline & & Test 1 & Test 2 & Test 1 & Test 2 & Test 1 & Test 2 & Test 1 & Test 2 \\
\hline \multirow{2}{*}{ Control } & Test 1 & & $\star 0.003$ & $0.001 *$ & $<0.001 *$ & $0.018 *$ & $<0.001 *$ & $0.668^{*}$ & $<0.001 *$ \\
\hline & Test 2 & $\star 0.003$ & & 0.999 & $<0.001 *$ & 0.999 & 0.18 & 0.999 & $<0.001 *$ \\
\hline \multirow{2}{*}{$\begin{array}{l}\text { LiTRE } \\
=50 \%\end{array}$} & Test 1 & $0.001 *$ & 0.999 & & 0.121 & 0.999 & 0.999 & 0.999 & $* 0.003$ \\
\hline & Test 2 & $<0.001 *$ & $<0.001 *$ & 0.121 & & 0.999 & 0.999 & $\star 0.005$ & 0.999 \\
\hline \multirow{2}{*}{ LiTRE 50-75\% } & Test 1 & $0.018^{*}$ & 0.999 & 0.999 & 0.999 & & 0.999 & 0.999 & 0.071 \\
\hline & Test 2 & $<0.001 *$ & 0.18 & 0.999 & 0.999 & 0.999 & & 0.687 & 0.081 \\
\hline \multirow{2}{*}{$\begin{array}{l}\text { LiTRE } \\
=75 \%\end{array}$} & Test 1 & 0.668 & 0.999 & 0.999 & $* 0.005$ & 0.999 & 0.687 & & $<0.001 *$ \\
\hline & Test 2 & $<0.001 *$ & $<0.001 *$ & $\star 0.003$ & 0.999 & 0.071 & 0.081 & $<0.001 *$ & \\
\hline
\end{tabular}

* Statistically Significant. 


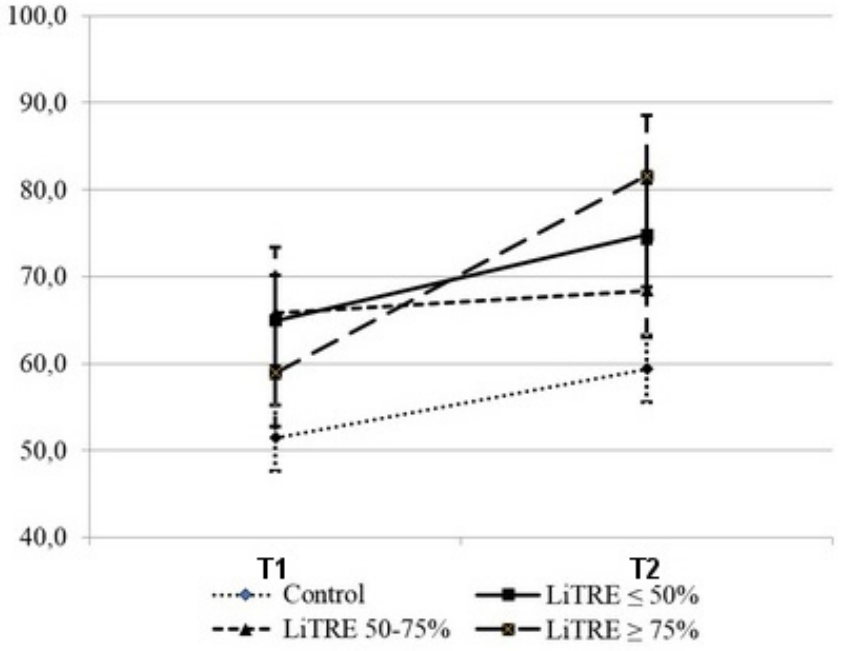

Figure 2. Means and respective 95\% confidence intervals for the scores of the four groups, the control one and the three LiTRE attendance subgroups, between tests 1 and 2 .

\section{DISCUSSION}

A considerable part of medical students presents a large gap in the concepts of trauma and emergency, although it is a matter of extreme relevance to the health professional ${ }^{2}$. The low average percentages found in the survey, between 51 and 66 points, for both groups, control and LiTRE, in the first test application, are in agreement with this scenario.

Trauma is the leading cause of death in individuals of up to 40 years of age in the Brazilian population and involves, in addition to costs in excess of $\mathrm{R} \$ 9$ billion, important social issues ${ }^{11}$. According to the Pan American Health Organization and the World Health Organization, 5.8 million people die from trauma each year worldwide, $32 \%$ more than the combined deaths from endemic diseases due to malaria, AIDS and tuberculosis ${ }^{12}$. Medical emergencies are similarly notorious for their characteristics that require thought, diagnosis and acute treatment. Time, in these circumstances, is essential to improve patients' prognosis. In order to develop this agility in attendance and perform good conducts, it is necessary for the medical student to have the consolidated theoretical contents. Poor teaching of the subject is an issue that needs to be deepened, especially when coupled with the still precarious institutionalization of residence programs in regulated areas in 2015 and the current health situation in the country. Of the 409,267 physicians working in Brazil, only 85 are graduates of some of the scarce twelve residency programs in Emergency Medicine in the country ${ }^{13}$.

In this research, after a year of undergraduate education offered by the university's traditional curriculum, we found a performance improvement in eight percentage points on the second test in relation to the first one in the control group. The numbers suggest, however, that only this structure as an isolated way of providing knowledge is inferior when dimensioned in the face of the new modalities of development of skills, competencies and formal content. The main result found in this study concerns the increase of more than 22 points, almost three times higher than the control, for the segment of the LiTRE with attendance greater than $75 \%$, considered by as a minimum to guarantee effective learning. The variables gender, age, school period and participation in other courses (such as the Nucleus of Teaching and Research in Emergency and Pre-hospital Care, offered by the university, among others) were controlled, so that the increase was related to learning in the league, save for some other confounding factor not accounted for. The strong association of attendance in LiTRE with the significant increase of the groups' grades, to the detriment of those under conventional methodology, evidences the need of supplementary formation of future professionals. This circumstance provides a differential between medical students who seek extracurricular activities in relation to those who do not $^{14}$. In similar studies, the results are also positive for students who participate in complementary activities, presenting a better learning curve and mastery of the subjects ${ }^{15,16}$.

In addition to the importance of promoting the knowledge of the participants, as evidenced by the increase in test score, analyzes on the subject demonstrate other benefits of extracurricular activities, such as integration with colleagues, supplementation of the course, feeling of well-being, attendance to professional inquiries and greater contact with society, promoting health and social transformation, expansion of critical sense and scientific reasoning ${ }^{9,10}$.

The perception of the relevance of these and other complementary structures, in consonance with the idealization of the "parallel" and "informal" curriculum, 
leads to ponder the need of integration and transposition of the extracurricular activities to the traditional education programs. However, some factors can be pointed out as obstacles to this process, such as difficulty of integration between disciplines and between theory and practice, strenuous workload of the usual curriculum with little time available for extracurricular activities, lack of political desire or material difficulties, such as a lack of physical structure and practice rooms,' lack of trained and available teachers, and high cost of laboratory skills and mannequins for simulated training ${ }^{10,17-19}$. Most of these points reflect the abscence of financial and research investments destined to the teaching of trauma and emergency, so that they are, therefore, delegated to extracurricular activities such as academic leagues and mentoring. Currently, projects such as "Situation of emergency and emergency education in undergraduate courses in medicine", developed by the Brazilian Association of Medical Education (ABEM), have tried to articulate the inclusion of this content in the current programs through strategies of gradual and phased teaching of the thematic ${ }^{2}$. In the first years, the students are inserted in programs of prevention of accidents, first aid and basic life support; in the following years, they are exposed to content and skills training in clinical medicine, pediatrics, gynecology-obstetrics and general surgery based on courses such as Advanced Trauma Life Support ${ }$, PreHospital Trauma Life Support $\circledast$ and Advanced Cardiovascular Life Support@; and finally, they experience the practice in prehospital care, in medical regulation, and in-hospital emergency care ${ }^{2}$.

Specifically, LiTRE complements the current curriculum of the UFF course, which does not have a compulsory discipline focused on theoretical teaching of trauma and emergency. In addition, it aids in the practical teaching of this content through simulations, considering that the university hospital faces difficulties, since its emergence sector functions as a referencing system, that is, there is no care by free demand, so that the experiences of trauma and emergency situations become limited. LiTRE also has programs to approach the population. Under projects entitled "LiTRE Saúde" and "LiTRE Educa", students offer specific training on how to act in daily emergencies to the population of Niterói, and to youth and adolescents in public schools. Over more than six years of the project, we estimate that about 3000 people have received the information for rapid recognition and activation of the medical service. In addition, basic life support courses are offered throughout the year in partnerships with the social precollege entrance examination and the academic directory of the university. In the scientific segment, the league enables research for publications and presentations at conferences and reviews on topics of relevance in its blog. All these aspects reinforce evidence of the fundamental presence of the leagues for medical and human formation and for the development of the skills and competences necessary to attend to both traumatic and non-traumatic emergencies.

The study had some limitations. The first one concerns the sample size of the interest group, ie the students in the league. It was not possible, for reasons of structure and management of the practical activities, to increase the number of members during the research year so that the sample size would be larger. This fact may be an explanation for the lack of statistical significance of score increase in groups with less than $75 \%$ of attendance, the number of students in this category possibly being insufficient for analysis. Another topic was the difficulty of making classes in the league exclusive to members, so that the control group did not attend them, which could generate bias in the study. Finally, the literature lacks well-defined variables that could influence the learning of these students and, therefore, were not included in the study, such as internships and presence in practice scenarios.

In conclusion, the present study demonstrated the improvement of the academic performance in trauma and emergency of the students participating in the LiTRE. The increase in knowledge was evident, especially when compared with a similar sample. The presence of complementary methods to the formal curriculum has proved important to increase the learning of medical students. LiTRE has been successfully pursuing strategies to improve its techniques and, consequently, to change the students' domain content deficit landscape. 


\title{
R E S U M O
}

\begin{abstract}
Objetivo: avaliar o crescimento do conhecimento dos integrantes da Liga de Trauma, Reanimação e Emergência em comparação com um grupo não participante, de características semelhantes, na Universidade Federal Fluminense. Métodos: foram avaliados 50 ligantes e 50 não ligantes (grupo controle), através de questionários aplicados no início e no fim de um ano letivo. Foi utilizado um modelo linear generalizado, com efeito de interação entre grupos e provas (comparações múltiplas com correção de Bonferroni). Foram incluídas como variáveis de controle: sexo, período, idade e realização de algum outro curso sobre tema similar. Resultados: observou-se um incremento de 22 pontos percentuais $(p<0,001)$ para o grupo com mais de $75 \%$ de presença na Liga em comparação aos oito pontos do grupo controle $(p<0,05)$. Não houve crescimento com significância estatística para o grupo com menos de $75 \%$ de presença. Conclusão: o crescimento de conhecimento foi significativamente maior no grupo assiduamente participante da Liga, o que reforça sua importância na complementação do conteúdo tradicional dos cursos de medicina.
\end{abstract}

Descritores: Ensino. Educação Médica. Estudantes de Medicina. Emergências. Traumatologia.

\section{REFERENCES}

1. Escolas Médicas do Brasil. Estudo comparativo mundial de escolas por país [Internet]. 2010. Acessado 2016 nov 19. Disponível em: http://www. escolasmedicas.com.br/intern2.php

2. Fraga GP, Pereira Jr GA, Fontes CER. A situação do ensino de urgência e emergência nos cursos de graduação de medicina no Brasil e as recomendações para a matriz curricular. In: Lampert JB, Bicudo AM, editores. 10 anos das Diretrizes Curriculares Nacionais dos cursos de graduação em Medicina. Rio de Janeiro: Associação Brasileira de Educação Médica; 2014. p. 41-56. Acessado 2016 Nov 23. Disponível em: http://abem-educmed.org.br/ wp-content/uploads/2016/06/Projetos_ABEM_ Diretrizes_Curriculares_Cap3.pdf

3. Brasil. Ministério da Saúde. DATASUS. Óbitos por causas externas segundo Unidade da Federação [Internet]. Brasília (DF): Ministério da Saúde; 2011 [citado 2016 Aug 1]. Disponível em: http://tabnet. datasus.gov.br/cgi/tabcgi.exe?sim/cnv/obt10uf.def

4. Sociedade Brasileira de Atendimento Integral ao Traumatizado; Sociedade Brasileira de Ortopedia e Traumatologia; Associação de Medicina Intensiva Brasileira; Sociedade Brasileira de Pediatra; Sociedade Brasileira de Neurocirurgia; Sociedade Brasileira de Anestesiologia; Colégio Brasileiro de Cirurgiões. Projeto trauma 2005-2025: sociedade, violência e trauma [Internet]. 2005. Acessado 2016 Aug 3. Disponível em: http://lateme.webnode.com.br/news/ projeto-trauma-2005-2025/

5. Barros JV, Dias RD. Impacto das internações de Urgência e Emergência no financiamento do Sistema Único de Saúde (SUS) no Brasil [Internet]. Brasília
(DF): Associação Brasileira de Economia da Saúde ABrES; 2013. Acessado 2016 Aug 6. Disponível em: http://abresbrasil.org.br/sites/default/files/avaliacao_ trabalho_10_impacto_das_internacoes_jacson.pdf

6. Brasil. Presidência da República, Casa Civil, Subchefia para Assuntos Jurídicos. Lei no 12.871 de 22 de outubro de 2013. Institui o Programa Mais Médicos, altera as Leis no 8.745, de 9 de dezembro de 1993, e no 6.932, de 7 de julho de 1981, e dá outras providências [Internet]. Brasília (DF); 2013. Acessado 2016 Aug 15. Available from: http://www.planalto. gov.br/ccivil_03/_ato2011-2014/2013/lei/12871.htm

7. Monteiro LLF, Cunha MS, Oliveira WL, Bandeira NG, Menezes JV. Ligas acadêmicas: o que há de positivo? Experiência de implantação da Liga Baiana de Cirurgia Plástica. Rev Bras Cir Plástica. 2008;23(3):158-61.

8. Pego-Fernandes PM, Mariani AW. Medical teaching beyond graduation: undergraduate study groups. Sao Paulo Med J. 2010;128(5):257-8.

9. Torres AR, De Oliveira GM, Yamamoto FM, Lima MCP. Ligas Acadêmicas e formação médica: contribuições e desafios. Interface (Botucatu). 2008;12(27):713-20.

10. Peres CM, Andrade AS, Garcia SB. Atividades extracurriculares: multiplicidade e diferenciação necessárias ao currículo. Rev Bras Educ Med. 2007;31(3):203-11.

11. Sociedade Brasileira de Atendimento integrado ao Traumatizado. Projeto de Atenção Nacional ao Trauma. 2014. Disponível em: http://www.sbait.org. br/projeto_trauma.php.

12. Organização Pan-America de Saúde; Organização Mundial de Saúde. Traumas matam mais que as três grandes endemias: malária, tuberculose e AIDS. Brasília (DF): OPAS/OMS; 2010. Disponível em: http:// www.paho.org/bra/index.php?option=com_conte. 
13. Sociedade Brasileira de Atendimento Integrado ao Traumatizado. Medicina de Emergência passa a ser especialidade no Brasil [Internet]. SBAIT News. 2015; Available from: https://sbaitbrasil.wordpress. com/2015/10/15/medicina-de-emergencia-passa-aser-especialidade-no-brasil/

14. Costa BEP, Hentschke MR, Silva ACC, Barros A, Salerno M, Poli-de-Figueiredo $C E$, et al. Reflexões sobre a importância do currículo informal do estudante de medicina. Sci Med (Porto Alegre). 2012;22(3):162-8.

15. Simões RL, Bermudes FAM, Andrade HS, Barcelos FM, Rossoni BP, Miguel GPS, et al. Trauma leagues: an alternative way to teach trauma surgery to medical students. Rev Col Bras Cir. 2014;41(4):297-302.

16. Ramalho AS, Silva FD, Kronemberger TB, Pose RA, Torres MLA, Carmona MJC, et al. Ensino de anestesiologia durante a graduação por meio de uma liga acadêmica: qual o impacto no aprendizado dos alunos? Rev Bras Anestesiol. 2012;62(1):63-73.

17. Feuerwerker L. Modelos tecnoassistenciais, gestão e organização do trabalho em saúde: nada é indiferente no processo de luta para a consolidação do SUS. Interface (Botucatu). 2005;9(18):489-506.

18. Maia JA. O currículo no ensino superior em saúde. In: Batista NA, Batista SH, orgs. Docência em saúde: temas e experiências São Paulo; SENAC; 2004. p.101-33.

19. Fraga GP, Quintas ML, Abib SCV. Trauma and emergency: is the unified health system (SUS) the solution in Brazil? Rev Col Bras Cir. 2014;41(4):232-3.

Received in: 06/09/2017

Accepted for publication: 26/10/2017

Conflict of interest: none.

Source of funding: none.

\section{Mailing address:}

Luciana Thurler Tedeschi

E-mail: tedeschi.luciana@gmail.com

(cc) BY 